\title{
WAGE GAP AS A POSSIBLE DETERMINANT OF GENDER INEQUALITY
}

\author{
Sabine Anete Vasina ${ }^{1}$, Biruta Sloka ${ }^{2}$ \\ University of Latvia (Latvia)
}

\begin{abstract}
Recent academic researchers have indicated that there are possible inequalities concerning work and pay in different countries, professions and economic sectors. The aim of current research is to analyse recent scientific findings on the wage gap depending on gender and empirical data in Latvia using EU-SILC surveys, Labour Surveys and monthly statistical data on wages and salaries for women and men. The findings indicated that in various economic fields and occupations women were under-represented, and amongst most of these fields the modal net wage interval for women was lower than the modal net wage interval for men. It was also concluded that in January 2018 the average gross income from work of women and men were statistically significantly different, confirming that men on average earned more than women.

KEYWORDS: wage gap, inequality, glass ceiling.
\end{abstract}

JEL CODES: J16, J 31.

DOI:

\section{Introduction}

Nowadays, in most countries women actively participate in labour market due to various circumstances. The rapid change in economic conditions might have a lot to do with the shift in social role system that has been cultivated for centuries, giving a chance for women to become aware of their individual rights to obtain education and participate in the workforce to maintain their households. In general, women have become more independent and mindful of their role in society, occupying various positions in both private and public sectors.

Along with women participation in the labour market, the attention of many societies has been brought to possible drawbacks in the workforce of the twenty-first century, such as different levels of employment and unmeasurable, but perceivable barriers that limit career opportunities for many women. These circumstances could influence the way women and men make their education and career choices, resulting to economic sectors in which one gender prevails more than the other and possibly creating gender wage gaps. It can also be suggested that wage gaps form due to low women participation in the labour market, also the choice of working full-time or part-time, considering the personal factors such as childcare.

The object of research - gender inequality in the context of occupational segregation among various economic sectors, gross and net income inequality at work in Latvia throughout the years 2015 to 2018.

The purpose of research is to analyse recent scientific findings on the gender wage gap and factors that limit gender inequality in the workforce, by examining empirical data in Latvia using EU-SILC surveys, Labour surveys, monthly statistical data on wages and salaries for women and men by sectors and professions.

1 Sabine Anete Vasina - student at the Management Science department, University of Latvia, Latvia Scientific interests: wage gap, gender inequality, occupational segregation

E-mail:VasinaSabine@gmail.com

2 Biruta Sloka - dr.oec, professor at the Management Science Department, University of Latvia, Latvia Scientific interests: quantitative analysis, higher education quality, work-based learning

E-mail: Biruta.Sloka@lu.lv 
The research methods used are analysis of scientific publications, analysis of statistical data obtained in Central Statistical Bureau of Republic of Latvia database, EU-SILC Surveys, Labour Force Surveys and other statistical data to check the statistical differences of wage gaps. For data analysis there were used descriptive statistics (indicators of central tendency or location, indicators of variability, indicators of skewness and indicators of kurtosis, data is analysed also by cross-tabulations; testing statistical hypotheses using several criteria: t-test; analysis of variance (ANOVA)).

\section{Theoretical findings}

In 1980's, a phrase glass ceiling related to gender inequality in the labour market first brought attention of American society (Cotter, Hermsen, Ovadia, Vanneman, 2001: 656) in a publication of "Wall Street Journal". Glass ceiling describes a situation in the workforce, when an invisible, but perceivable barriers limit gender equality, interfering with career advancement of women in spite of their qualification or achievements. Glass ceiling has been on agenda for many researchers before, analysing the significant under-representation of women in corporate leadership positions (Glass, Cook, 2016: 51) and so called glass cliff that describes a situation in which women are appointed to more risky leadership positions (Ryan, Haslam, Morgenroth, Rink, Stoker, Peters, 2016: 446). D. Cotter et al. (Cotter, Hermsen, Ovadia, Vanneman, 2011: 656) propose that gender inequality in the workforce arises between top management roles, in relation Z. Othman stated that gender inequality does not vanish even in situations when women and men have matching levels of education and experience (Othman, 2015: 27). Wage gaps in different countries have small differences but they are present in many countries - the United Kingdom (Shannon, Kidd, 2005: 361), the United States of America (Sayers, Levendis, Dicle, 2017: 1851), Belgium (Rycx, Tojerow, 2004: 287), in Spain (Scicchitano, 2014: 340), Australia (Chang, Conne11, Burgess, Travaglione, 2014: 773), Greece (Livanos, Pouliakas, 2012: 572), Lithuania (Šimanskienè, Sandu, 2013: 206), Mexico (Bhalotra, Fernández, Venkataramani, 2015: 339). The empirical methods have been already used to study the consequences of under-representation of women in top positions for the overall gender pay gap in Canada, Sweden and the United Kingdom (Fortin, Bell, Bohm, 2017: 107) using Labour Force Surveys. A wage gap is also common in middle income countries (Almasifard, 2018: 152). A wage gap and glass ceiling were on research agenda also for researchers from France (Barnet- Verzat, Wolff, 2008: 496) who have performed deep analysis in a big company in the defence and space sectors. Some scholars suggest that the gender pay gap might reflect the pattern of institutions and policies prevailing in each country (Christofides, Polycarpou, Vrachimis, 2013: 101). Gender wage differences have also been studied in the Baltic countries (Šilingienè, Radvila, 2014: 98) concluding that the gender pay gap is one of the most major economic and social problems.

In research conducted in the USA, 50\% of women admitted they had earned less than their men-colleagues when completing the same tasks. The same research concluded that gender inequality becomes more severe for women that have higher level of education (Pew Research Center, 2017) therefore it can be foreseen that gender pay gap becomes more severe in top management roles, resulting in different levels of income between various professions and industrial sectors. This has also been approved in research conducted between two homogeneous groups of highly-educated women and men working in one specific sector in similar jobs in Germany (Grund, 2015: 124) when men employees qualified for higher bonuses and higher fixed salaries. Different factors influencing a wage gap including the importance and influence of education level (Couppié, Dupray, Moullet, 2014: 387), family background (Cho, Heshmati, 2015: 31), native or foreign employee (Mavromaras, 2004: 317) and many other factors are on research agenda for many researchers.

To understand how gender inequality arises in the workforce, it is important to primarily take into consideration how gender is presumed. The term "gender", often called as "social gender" in most theoretical frameworks, is related to how culture, social interactions and family values shape an individual (Eckert, Ginet, 2013). Other theorists anticipate that gender roles have been constructed and carried over centuries describing historical division of labour between men and women (McGinn, Eunsil, 2017: 84). One of the most recognised theories, social role theory, first adapted by Alice Eagly (Eagly, Wood, Diekman, 2000: 127), outlines how society beliefs determine behaviour of women and men in the workforce. It is important to 
make an emphasis on this to further examine how the essence of gender itself affects the labour market. By taking social roles into consideration, it has been revealed that individuals acquire the necessary skills for their roles, creating professions and qualifications in which one gender dominates more than the other (Eagly et al., 2000: 117), possibly being one of the determinants of inequality resulting to gender pay gap. In report of research carried in Latvian companies in 2014, it was concluded that women and men might make their education and career choices based on stereotypes and gender roles prevailing in Latvian society (Sabiedribas integracijas fonds, 2014). In the same research respondents stated that technical work is more suitable for men, but women should take roles in healthcare, which is an indicative of role stereotyping. Some researchers have found, that the consequences of gender stereotypes are related to many forms of discrimination in the labour market, for instance, stereotypical job role distribution between women and men, a wage gap and different levels of employment (Mihalcova, Pruzinsky, Gontkovicova, 2015: 1261). It has been concluded that one of the most significant determinants of income inequality in the Slovakian labour market is gender stereotyping (Mihalcova, Pruzinsky, Gontkovicova, 2015: 1264) and such factors that limit women career growth have been previously examined and divided into three blocks consisting of social, personal and organisational factors in Croatia (Vokic, Coric, Obadic, 2017: 257). Researchers from France (Palomino, Peyrache, 2010: 570) have found that an equal-opportunity policy for both genders would not eliminate the wage gap, as long as there is a presence of bias, in this case women will always earn less than men. Empirical research before (Cho, 2016: 175) have been done to analyse how fairness and values regarding gender equality in society promote social trust and reducing gaps among people in society itself.

Apart from social roles and stereotyping, there are other possible circumstances resulting in the gender pay gap. W. Farrell (Farrell, 2005: 29) describes a situation that occurs between men and women with no level of education and their choice based on either high level of income or safe work environment. For example, a pay gap can be related to women choosing the safe work environment and working as clerks or cashiers, but men earning more by choosing the unsafe work environment, such as construction or firefighting. It can be presumed that in some countries the gender pay gap is related to low participation of women in labour markets and circumstances, such as childcare, that lead women to work part-time. For example, due to low participation in the labour market in 2016, the highest gender pay gap between the EU Member States was recorded in the Czech Republic (16.0 p.p.), Romania (17.6 p.p.), Greece (19.0 p.p.), Italy (20.1 p.p.) and Malta (27.7 p.p.) (Eurostat, 2018). In the EU in 2017, there were 52,6 thousand women and 23,4 thousand men working part-time (Eurostat, 2018). According to Central Statistical Bureau of Latvia (Central Statistical Bureau of Latvia, 2017) in 2017, on average, the gender pay gap between those employed fulltime was $18.7 \%$, whereas part-time $-22.7 \%$.

\section{Empirical research results}

Similar researches have been conducted before, when wage gaps were studied in more detail in Europe, by obtaining the data from EU-SILC surveys, analysing country work-family reconciliation policies, labour market institutions and also maternity leave policies (Christofides, Polycarpou, Vrachimis 2013: 86). To analyse labour market differences by gender from 2015 to 2017, the authors of this research used anonymised Labour Force Surveys data provided by the Central Statistical Bureau of Latvia. These surveys consist of information in accordance to Standard Occupational Classification (SOC) system in Latvia, that is consistent with international practice and is defended by International Labour Organisation's International Standard Classification of Occupations (ISCO-08), maintaining a profession classifier, that consists of 10 main groups, corresponding subgroups and small groups. In 2016, there were 42,04 thousand respondents, 23,5 thousand $(55.7 \%)$ of them being women. 


\subsection{Gender distribution among positions and occupations from 2015 to 2017}

It has been observed, that in some positions or occupations one gender dominates more than the other. Women choose to work as professionals, technicians and associate professionals, service and sales workers, whilst a large proportion of men work as craft and related trades workers, plant and machine operators and assemblers.

Table 1. Gender position / occupation in Latvia according to Standard Occupational Classificator (SOC) from 2015 to 2017

\begin{tabular}{|l|c|c|c|c|c|c|}
\hline & \multicolumn{3}{|c|}{ Women } & \multicolumn{3}{c|}{ Men } \\
\hline $\begin{array}{l}\text { Position/occupation in accordance to Standard } \\
\text { Occupational Classificator (SOC) }\end{array}$ & $\mathbf{2 0 1 5}$ & $\mathbf{2 0 1 6}$ & $\mathbf{2 0 1 7}$ & $\mathbf{2 0 1 5}$ & $\mathbf{2 0 1 6}$ & $\mathbf{2 0 1 7}$ \\
\hline Managers & 754 & 787 & 841 & 846 & 815 & 877 \\
\hline Professionals & $\mathbf{2 0 4 8}$ & $\mathbf{2 1 0 1}$ & $\mathbf{2 2 0 3}$ & 753 & 754 & 779 \\
\hline Technicians and associate professionals & $\mathbf{1 4 2 2}$ & $\mathbf{1 4 4 2}$ & $\mathbf{1 4 4 5}$ & 787 & 808 & 843 \\
\hline Clerical support workers & 683 & 675 & 648 & 182 & 183 & 196 \\
\hline Service and sales workers & $\mathbf{2 0 7 8}$ & $\mathbf{2 0 6 9}$ & $\mathbf{2 1 0 3}$ & 608 & 592 & 654 \\
\hline Skilled agricultural, forestry and fishery workers & 296 & 336 & 305 & 544 & 560 & 492 \\
\hline Craft and related trades workers & 422 & 531 & 505 & $\mathbf{1 8 3 3}$ & $\mathbf{1 7 8 8}$ & $\mathbf{1 7 7 4}$ \\
\hline Plant and machine operators and assemblers & 127 & 132 & 177 & $\mathbf{1 6 4 5}$ & $\mathbf{1 6 2 4}$ & $\mathbf{1 6 7 3}$ \\
\hline Elementary occupations & 1225 & 1223 & 1261 & 1093 & 1117 & 1215 \\
\hline Armed forces occupations & 12 & 12 & 19 & 54 & 63 & 81 \\
\hline
\end{tabular}

Source: the authors' calculations based on data from Central Statistical Bureau of Latvia: Anonymised Labour Force Surveys in 2015, 2016, 2017.

On average, the employment of women in clerical support is 3.6 times higher than of men's, similarly in service and sales, where the proportion of women is 3.4 times higher than that of men. This situation confirms the proposition previously mentioned, when women make their career choices based on the safe work environment, ability to work in shifts, but men tend to take occupations in technical fields, for example, craft and trades (men being 3.7 times more) and work as plant, machine operators and assemblers (men being 11.4 times more). The authors propose that gender distribution between positions and occupations could result in a wage gap due to many reasons - historical division of labour that might influence career choices, pay differences in the classified groups, the work environment and work specifics, the necessary level of education or qualification.

\subsection{Gender economic activity of the main job local unit in 2016}

To evaluate how the gender pay gap might be a determinant of income inequality, the authors chose to explore gender economic activity of the main job local units and average wages in Latvia. The most recent data on the wage gap in the year 2016 was provided by Eurostat, therefore this certain period of time was chosen due to limited availability of data.

The lowest wage gaps have been recorded in units of construction $(5.3 \%)$ and public administration, defence and social security $(0.1 \%)$. It is possible to conclude that a wage gap in construction might not be a possible determinant of income inequality, due to the fact that the men employment in this unit is 11.9 times higher than of women. The authors propose that the low employment of women in this unit is due to dangerous work conditions and physically hard job specifics. When analysing the low wage gap in public administration, it is possible to propose that wages in public sector are determined by the regulations of institution, therefore forming greater gender equality. 
Table 2. Gender economic activity of the main job local unit, average net wage and wage gap in 2016 (based on Classification of Economic Activities in the European Union, NACE Rev. 2)

\begin{tabular}{|c|c|c|c|c|}
\hline Economic activity of main job local unit & Women & Men & $\begin{array}{c}\text { Average net } \\
\text { wage, euro }\end{array}$ & \begin{tabular}{|l} 
Wage gap, \\
$\%$
\end{tabular} \\
\hline Agriculture, forestry and fishing & 596 & 1065 & 606 & $\mathrm{n} / \mathrm{a}$ \\
\hline Manufacturing, mining and quarrying & 1234 & 1924 & 685 & 18.6 \\
\hline Construction & 95 & 1138 & 618 & 5.3 \\
\hline $\begin{array}{l}\text { Wholesale and retail trade, accommodation and food service } \\
\text { activities }\end{array}$ & 1944 & 908 & 498 & $\mathbf{1 7 . 6}$ \\
\hline Transportation and storage, information and communication & 550 & 1340 & 818 & 10.2 \\
\hline $\begin{array}{l}\text { Financial and insurance activities; real estate activities; professional, } \\
\text { scientific and technical activities }\end{array}$ & 941 & 730 & 803 & 22.5 \\
\hline Public administration and defence; compulsory social security & 709 & 541 & 776 & 0.1 \\
\hline Education & 1569 & 286 & 511 & -4.4 \\
\hline Human health and social work activities & 1033 & 169 & 579 & 19.1 \\
\hline Other activities & 632 & 198 & 544 & $\mathrm{n} / \mathrm{a}$ \\
\hline
\end{tabular}

Source: the authors' calculations based on data from Central Statistical Bureau of Latvia: Anonymised Labour Force Survey in 2016, Average monthly wages by type of economic activity; Eurostat: Gender pay gap in adjusted form by

NACE Rev. 2 activity

Education is the only unit in which women on average earn more than men, resulting in a negative of $4.4 \%$ in 2016. In general, the women employment in this sector is 5.5 times higher than of men. Although, as mentioned previously, the gender pay gap in the public sector might indicate equal possibilities, the average net wage in education is the second lowest (511 euros/net) after wholesale and retail trade (498 euros/ net). Career choices might be taken into account mainly due to the fact that the majority of women choose to work in the lowest-paying units of a country in sense of the average net wage, for example, education, human health and social work, wholesale and retail trade. By comparing education and wholesale units, it is possible to say, that, although the women employment in these sectors dominate, the gender pay gap of $17.6 \%$ in wholesale and retail trade indicates possible gender inequality in this unit. It should be taken into account that women might be choosing to work part time in this unit, what results in high income differences.

Similarly as in the unit of wholesale and retail trade, the large gender pay gap of $19.1 \%$ might indicate gender inequality in the unit of human health and social work activities. As commonly known, the wide pay gap in this unit might be influenced by the level of education and career opportunities, as well as stereotypes leading to discrimination, for example, beliefs that one gender has more skills to do certain tasks (a typical example of this would be that in society men are considered to be better doctors than women).

The highest wage gap of $22.5 \%$ in 2016 have been recorded in the unit of financial and insurance activities; real estate activities; professional, scientific and technical activities. The wage gap in financial and insurance activities was $29.4 \%$ in 2015 and $25.9 \%$ in 2016 . Although the level of women employment was for $22.4 \%$ higher than that of men, the average wage being 803 euros net, men on average in this sector earned $22.5 \%$ more than women. This can be considered as a possible determinant of gender inequality in this unit and should be analysed in more detail.

\subsection{Analysis of net wages in anonymous Labour Surveys}

To determine whether there is a possible gender inequality between respondents of Labour Surveys throughout the years 2016 and 2017, the authors chose to explore wage differences between sectors and compare them to the gender pay gap statistics provided by Eurostat. The table below indicates modal wages based on local units. 
Table 3. Net wage modal intervals of women and men based on economic activity of the main job local unit in 2016 and 2017.

\begin{tabular}{|c|c|c|c|c|}
\hline & \multicolumn{2}{|c|}{2016} & \multicolumn{2}{|c|}{2017} \\
\hline & \multicolumn{4}{|c|}{ Net wage modal interval } \\
\hline Economic activity of the main job local unit & Women & Men & Women & Men \\
\hline Agriculture, forestry and fishing & $0-331$ & $450-700$ & \multicolumn{2}{|c|}{$450-700$} \\
\hline Manufacturing, mining and quarrying & $331-450$ & $450-700$ & $340-450$ & $450-700$ \\
\hline Construction & \multicolumn{2}{|c|}{$450-700$} & \multicolumn{2}{|c|}{$450-700$} \\
\hline $\begin{array}{l}\text { Wholesale and retail trade, accommodation } \\
\text { and food service activities }\end{array}$ & $0-331$ & $450-700$ & \multicolumn{2}{|c|}{$450-700$} \\
\hline $\begin{array}{l}\text { Transportation and storage, information and } \\
\text { communication }\end{array}$ & \multicolumn{2}{|c|}{$450-700$} & $0-340$ & $450-700$ \\
\hline $\begin{array}{l}\text { Financial and insurance activities; real } \\
\text { estate activities; professional, scientific and } \\
\text { technical activities }\end{array}$ & $0-331$ & $450-700$ & $0-340$ & $450-700$ \\
\hline $\begin{array}{l}\text { Public administration and defence; } \\
\text { compulsory social security }\end{array}$ & \multicolumn{4}{|c|}{$450-700$} \\
\hline Education & \multicolumn{4}{|c|}{$450-700$} \\
\hline Human health and social work activities & $450-700$ & $331-450$ & $340-450$ & $0-340$ \\
\hline
\end{tabular}

Source: the authors' calculations based on data from Central Statistical Bureau of Latvia: Anonymised Labour Force Survey in 2016 and 2017.

The statistical analysis of net wage modal intervals in 2016 proves similar results on the data of the gender pay gap among units reported in the labour market, in sense that women earn less in such branches as wholesale and retail trade, financial and insurance activities, manufacturing. The most equal units in 2016 and 2017 were construction, education, public administration and defence. The data provided by Eurostat confirms these units as the most gender equal, due to the lowest wage gaps in 2016. In 2016 and 2017, in contradiction to the data provided by Eurostat, net wage modal interval was higher for women in human health and social work activities. It can be foreseen that the data of the gender pay gap and Anonymous Labour Force Surveys have similarities and can be used to predict possible situation in the workforce.

\subsection{Statistical hypothesis testing two sample means}

In Table 4, it is indicated that in January 2018 the median class interval for women was 500-700 euros, and for men $-700-1000$ euros, suggesting potential wage inequalities. The median of gross wages for women was 687.60 euros, whereas for men -758.06 euros. The median describes a situation in which $50 \%$ of women earned 687.60 euros gross or less, whilst $50 \%$ of women earned 687.60 euros gross or more. The same proposal is applied to gross wages of men, reporting that $50 \%$ of men earned 768.06 euros gross or less, whilst other 50\% earning more than the median calculated.

Table 5 summarizes the measures calculated to determine the mode salaries for women and men. The mode indicates the most common gross salary, based on its appearance between women and men. The modal intervals were determined by considering the data shown in Table 7, indicating that modal gross salary interval for women and men in January 2018 was 700-1000 euros.

The mode indicates, that the most frequent gross salary for women in Latvia in January 2018 was 825.43 euros, and 920.38 euros - for men. 
Table 4. The data used to determine the median value of men and women gross wages in Latvia, January 2018

\begin{tabular}{|c|c|c|}
\hline & Women & Men \\
\hline Median Interval, euro & $500-00$ & $700-1000$ \\
\hline Length of the median interval, $\Delta$ & 200 & 200 \\
\hline Lower limit, $x_{0}$ & 500 & 700 \\
\hline Cumulative frequency of the interval below, $S_{\mathrm{Me-1}}(\%)$ & 33.07 & 43.89 \\
\hline$w_{M e}(\%)$ & 18.05 & 21.05 \\
\hline Median & 687.60 & 758.06 \\
\hline
\end{tabular}

Source: the authors' calculations based on data from Central Statistical Bureau of Latvia: Breakdown of number of employees by monthly gross income by sex, DS21.

Table 5. The data used to determine the mode value of men and women gross wages in Latvia, January 2018

\begin{tabular}{|c|c|c|}
\hline & Women & Men \\
\hline Modal Interval, euro & $700-1000$ & $700-1000$ \\
\hline Length of the modal interval, $\Delta$ & 300 & 300 \\
\hline Lower limit, $x_{0}$ & 700 & 700 \\
\hline Frequency of the interval below $w_{M a-1}(\%)$ & 18.05 & 14.85 \\
\hline$w_{M_{0}}(\%)$ & 21.57 & 21.05 \\
\hline Frequency of the interval above, $w_{M_{0+1}}(\%)$ & 16.67 & 18.81 \\
\hline Mode, euro & 825.43 & 920.38 \\
\hline
\end{tabular}

Source: the authors' calculations based on data from Central Statistical Bureau of Latvia: Breakdown of number of employees by monthly gross income by sex, DS21.

The further examination of the asymmetry in both distributions, the relationships between mode, median and mean should be studied. The asymmetry coefficient (coefficient of skewness) describes the skewness of distribution. It can also be predicted that the distribution of gross salaries for women and men are positively skewed, indicating, that the gross income is not distributed equally. The both means being greater than the modes and the means being greater than the medians indicate the positively skewed distributions of both men and women gross wages. The coefficient of skewness was calculated by subtracting mode from mean and dividing it by standard deviation. The coefficient of Skewness was 0.042 for women and 0.093 for men, proving the distribution to be positively (right) skewed.

The coefficient of Kurtosis describes the flatness or peakedness of the distribution. In this case, the coefficient of Kurtosis for gross wages of women is 2.654 and for men is 2.770 meaning the distributions to be more high-peaked in comparison to the normal distribution.

The distribution of women and men gross wages is shown in Figure 1. It is possible to perceive that the skewness for women and men is positive, due to the distribution being more leaned to the left side and the tale of this distribution being longer on the right side. The higher peak of distribution for women gross salaries describes how a higher number of women earn up to the gross mean of 855.03 euros. It can also be perceived that inequality of gross wages arise on the left side of the tale as well as on the right side. The modal gross income for women is $10.3 \%$ lower than the modal gross income for men. The authors propose that the gender pay gap arises due to: 1) a higher number of women earning lower salaries; 2) a higher number of men earning higher salaries, which is indicated on the right long side of the tale. 
Table 6. The mean, mode, median and skewness of women and men gross wages in Latvia, January 2018

\begin{tabular}{|c|c|c|}
\hline & Women & Men \\
\hline Weighted arithmetic mean $\mu$ (euro) & 855.03 & 1002.63 \\
\hline Mode, Mo & 825.43 & 920.38 \\
\hline Median, Me & 687.60 & 758.06 \\
\hline Standard deviation, $\sigma$ (euro) & 690.09 & 883.56 \\
\hline Skewness & 0.042 & 0.093 \\
\hline Kurtosis & 2.654 & 2.770 \\
\hline
\end{tabular}

Source: the authors' calculations based on data from Central Statistical Bureau of Latvia: Breakdown of number of employees by monthly gross income by sex, DS21.



Fig. 1. Gross income ${ }^{3}$ distribution from work of women and men in Latvia, January 2018

Source: the authors' created graph based on the Central Statistical Bureau of Latvia data, 2018.

The authors chose to conduct statistical hypothesis for testing two sample means so that to determine whether further research should be conducted in the nearest future and the results indicate a possible gender inequality in gross income from work. The data was obtained through database of Central Statistical Bureau of Latvia. Both observations were unrelated, because the analysis was conducted on two independent sets of data.

The statistical hypotheses, to analyse average gross income difference between men and women in January 2018, were as following:

$\boldsymbol{H}_{\boldsymbol{o}}$ : In January 2018, the average gross income of men and women were with no significant difference.

$\boldsymbol{H}_{1}$ : In January 2018, the average gross income of men and women were significantly different.

In Table 6, it is indicated that in January 2018 there were 405.9 thousand women and 383,4 thousand men employed receiving income from work. The arithmetic mean of wages for women was 855.03 euros, and for men 1002.63 euros. The arithmetic mean of wages for men exceeds the mode and median, appointing that a large proportion of men earn higher salaries, affecting the indicator of weighted arithmetic mean. It is indicated that the variance of men is much more spread $\left(\sigma^{2}=780676.21\right)$ than the variance of women $\left(\sigma^{2}=476224.17\right)$, appointing men are more unequal between themselves. The variance of women indicates that women are more equal between themselves. The standard deviation describes how the gross wages of

3 According to CSB of Republic of Latvia, Income includes all gross income calculated in salaried job from which income tax paid by an employee is withheld (including non-taxable minimum, tax relieves, the eligible expenses for which the taxpayer has the right to reduce taxable income, statutory state social security contributions). 
Table 7. Distribution of average gross income of men and women in Latvia, January 2018 and the main results for testing statistical hypothesis

\begin{tabular}{|c|c|c|c|}
\hline \multirow{2}{*}{ Gross income interval, EUR } & \multirow{2}{*}{ Interval Midpoint, $x_{i}$} & \multicolumn{2}{|c|}{ Count, $f_{i}$} \\
\hline & & Women, $f_{i s}$ & Men, $f_{i x}$ \\
\hline Up to 70.00 & 35 & 8517 & 8844 \\
\hline $70.01-150.00$ & 110 & 11484 & 11393 \\
\hline $150.01-300.00$ & 225 & 27212 & 22762 \\
\hline $300.01-500.00$ & 400 & 87005 & 68362 \\
\hline $500.01-700.00$ & 600 & 73269 & 56952 \\
\hline $700.01-1000.00$ & 850 & 87532 & 80735 \\
\hline $1000.01-1500.00$ & 1250 & 67664 & 72117 \\
\hline $1500.01-2000.00$ & 1750 & 22401 & 29119 \\
\hline $2000.01-2500.00$ & 2250 & 9512 & 13061 \\
\hline $2500.01-3000.00$ & 2750 & 4662 & 7075 \\
\hline $3000.01-4000.00$ & 3500 & 3801 & 6722 \\
\hline $4000.01-5000.00$ & 4500 & 1426 & 2791 \\
\hline $5000.01-6000.00$ & 5500 & 590 & 1273 \\
\hline Over 6000.00 & 6500 & 803 & 2246 \\
\hline \multicolumn{2}{|c|}{ Number of persons with income from work } & 405878 & 383452 \\
\hline \multicolumn{2}{|c|}{ Weighted arithmetic mean of income from work $\mu$ (euro) } & 855.03 & 1002.63 \\
\hline \multicolumn{2}{|c|}{ Mode, $M o$} & 825.43 & 920.38 \\
\hline \multicolumn{2}{|l|}{ Median, $M e$} & 687.60 & 758.06 \\
\hline \multicolumn{2}{|l|}{ Variance, $\sigma^{2}$} & 476224.17 & 780676.21 \\
\hline \multicolumn{2}{|l|}{ Standard deviation, $\sigma$ (euro) } & 690.09 & 883.56 \\
\hline \multicolumn{2}{|c|}{ Standard error of difference of arithmetic means $S_{\bar{x}_{1}-\bar{x}_{2}}$} & \multicolumn{2}{|l|}{1.78} \\
\hline \multicolumn{2}{|l|}{ t-statistic } & \multicolumn{2}{|l|}{82.96} \\
\hline
\end{tabular}

Source: the authors' calculations based on data from Central Statistical Bureau of Latvia: Breakdown of number of employees by monthly gross income by sex, DS21.

men and women is spread around the weighted arithmetic mean, e.g., $68.28 \%$ of women gross income from work lies in interval of $855.03 \pm 690.09$ euros, but $68.28 \%$ of men gross income from work lies in interval of $1002.63 \pm 883.56$ euros.

It was concluded, that average gross income of women and men in January 2018 were statistically significantly different $(0,000)$. The t-statistic of 82.96 indicates the large observed difference between two means, rejecting the null hypothesis $\left(t=82.96, \sigma_{\text {women }}=690.09, \sigma_{\text {men }}=883.56\right)$ with a very high probability (sig. 0,000$)$.

\section{Conclusions}

Most investigation considering the possible reasons of income inequality in the workforce have been based on the analysis of barriers that limit the career advancement of women. Such unperceivable barriers as biases, gender stereotyping and social roles have been mentioned as one of the most important factors resulting in glass ceiling. Between some opinions, the typical choice of occupation and work specifics is related to the historical job division between women and men. Other circumstances, resulting in gender inequality and the pay gap, have been related to women choosing the safe work environment and flexible working hours, and in some countries the gender pay gap might be formed due to low women participation in the labour market.

Due to the limitations of data availability, the time period analysed was the years from 2015 to 2017. The research findings indicated that there were positions or occupations over-represented by one gender between this time period. The occurrence of such situation can result in the gender pay gap between various organisational levels. The 
occurrence of the wage gap could also be related to choosing to work in an economic branch that is less paid. After analysing the data on wage gaps in every economic sector of Latvia, it was concluded that the lowest wage gaps in 2016 were recorded in the units of construction and public administration, defence and social security. It was also suggested, that the low wage gap in construction was formed due to low women participation in this unit and related to dangerous work conditions and physically hard job specifics. The low wage gap in public administration might be related to the previously defined salary regulations of public institutions. Education was the only sector in which women on average earned more than men, although, the average net wage in education was the second lowest, being able to suggest a possible formation of the gender wage gap in the overall workforce. There might be a possible gender inequality in the unit of wholesale and retail trade, due to the high level of women representation, but a gender pay gap of $17.6 \%$. Such as pay inequality occurred in human health and social work activities, which is considered to be one of the most sensitive branches to stereotyping. The highest wage gap of $22.5 \%$ was recorded in financial and insurance related activities, in which employment of women was for $22.4 \%$ higher than of men, gender pay gap being a possible determinant of gender inequality.

In the analysis of employees by monthly gross income from work in January 2018, it was concluded that the median gross interval for women was 500-700 euros, and 700-1000 euros for men, suggesting potential wage inequalities. It was concluded onwards that the median gross wage, gross mode wage and gross mean wage for men was higher than for women, and the most frequent salary between women in Latvia was 825.43 euros, whereas for men it was 920.38 euros. The gross income salaries for women and men were positively skewed, indicating, that the gross income was not distributed equally resulting to the distribution being leaned to the left side and its tale being longer on the right side. It was perceived that gender pay gap arises due to a higher number of women earning lower salaries and a higher number of men earning higher salaries. After the testing of statistical hypothesis on the difference between average gross income of men and women in January 2018 it was mainly concluded that the variance of men was much more spread than the variance of women, indicating that men are more unequally paid between themselves. It was concluded, that the average gross income of women and men in this period were statistically significantly different $(0,000)$, rejecting the null hypothesis with a very high probability (sig. 0,000 ). The authors conclude that in the month analysed it was shown that there are statistically significant differences between average gross incomes from work between both genders, therefore further research should be conducted to examine whether there is the same appearance of gender pay inequality in the months following January 2018. The following months should be analysed separately using the same approach and median, mode values and standard deviations must be calculated along with the statistical hypothesis tests. The authors propose that the same approach should be taken to conduct the same analysis to determine whether average gross incomes from work are with a statistically significant difference between economic sectors and professions, for example, testing men and women average gross incomes in economic sectors with the highest wage gaps in Latvia, such as finance, human health, manufacturing and wholesale, retail trade to gain a more deeper insight about possible inequality in these sectors.

\section{Acknowledgements}

The paper was supported by the National Research Program 5.2. EKOSOC-LV and National Research Program INTERFRAME.

\section{References}

Almasifard, M. (2018). Gender Wage Gap in Selected Developing Upper-Middle Income Countries. International Journal of Development Issues, Vol. 17, No. 2, pp. 142-156.

Barnet-Verzat, C., Wolff, F.-C. (2008). Gender Wage Gap and the Glass Ceiling Effect: A Firm- Level Investigation. International Journal of Manpower, Vol. 29, No. 6, pp. 486-502.

Bhalotra, S. R., Fernández, M., Venkataramani, A. S. (2015). The Right Tail and the Right Tale: The Gender Wage Gap in Mexico. Research in Labor Economics, Vol. 41, pp. 299-341.

Central Statistical Bureau of Latvia (2015-2017). Individual data for educational activities. 
Central Statistical Bureau of Latvia (2018). Full-time and part-time employed by sex, NBG11.

Central Statistical Bureau of Latvia. (2018). Average monthly wages by type of economic activity, DSG03.

Central Statistical Bureau of Latvia. (2018). Breakdown of number of employees by monthly gross income by sex. DS21.

Chang, J., Connell, J., Burgess, J., Travaglione, A. (2014). Gender Wage Gaps in Australian Workplaces: Are Policy Responses Working? Equality, Diversity and Inclusion: An International Journal, Vol. 33, No. 8, pp. 764-775.

Cho, S. (2016). Does Gender Equality Promote Social Trust? An Empirical Analysis. World Development, Vol. 88, pp. $175-187$.

Cho, S., Heshmati, A. (2015). What if You had been Less Fortunate: The Effects of Poor Family Background on Current Labor Market Outcomes. Journal of Economic Studies, Vol. 42, No. 1, pp. 20-33.

Christofides, L., Polycarpou, A., Vrachimis, K. (2013). Gender Wage Gaps, "Sticky Floors" and "Glass Ceilings" in Europe. Labour Economics, Vol. 21, Issue C, pp. 86-102.

Cotter, D., Hermsen, J., Ovadia, S., Vanneman, R. (2001). The Glass Ceiling Effect. Social Forces, Vol. 80, No. 2, pp. 655-681.

Couppié, T., Dupray, A., Moullet, S. (2014). Education-based Occupational Segregation and the Gender Wage Gap: Evidence from France. International Journal of Manpower, Vol. 35, No. 3, pp. 368-391.

Eagly, A. H., Wood, W., Diekman, A. B. (2000). Social Role Theory of Sex Differences and Similarities: A Current Appraisal. In T. Eckes \& H. M. Trautner (Eds.). The Developmental Social Psychology of Gender, pp. $123-174$. Mahwah: Lawrence Erlbaum Associates Publishers.

Eckert, P., Ginet, S. (2013). Language and Gender. New York: Cornell University. pp. 1-24.

European Commision, EurosStatistical Office. (2016). Gender statistics.

European Commission, EurosStatistical Office. (2016). Gender pay gap in unadjusted form by NACE Rev.2 Activity.

Farrell, W. (2005). Why Men Earn More: The Startling Truth Behind the Pay Gap and what Women can do about it. American Management Association, pp. 1-270.

Fortin, N., Bell, B., Bohm, M. (2017). Top Earnings Inequality and the Gender Pay Gap: Canada, Sweden and the United Kingdom. Labour Economics, Vol. 47, pp. 107-123.

Glass, C., Cook, A. (2016). Leading at the Top: Understanding Women's Challenges above the Glass Ceiling. The Leadership Quarterly, Vol. 27, No. 1, pp. 51-63.

Livanos, I., Pouliakas, K. (2012). Educational Segregation and the Gender Wage Gap in Greece. Journal of Economic Studies, Vol. 39, No. 5, pp. 554-575.

Mavromaras, K. G. (2004). Wage Differentials between Male- Female and Native- Foreign Workers in Pre- unification Germany. International Journal of Manpower, Vol. 25, No. 3/4, pp. 300-320.

McGinn, K., Eunsil, O. (2017). Gender, Social Class, and Women's Employment. Current Opinion in Psychology, Vol. 18, pp. 84-88.

Mihalcova, B., Pruzinsky, M., Gontkovicova, B. (2015). The Consequences of Gender Stereotypes in The Work of Managers. Procedia Economics and Finance, Vol. 23, pp. 1260-1265.

Othman, Z., Othman, N. (2015). A Literatural Review on Work Discrimination among Women Employees. Asian Social Science, Vol. 11, No. 4, pp. 26-32.

Palomino, F., Peyrache, E. (2010). Psychological bias and Gender Wage Gap. Journal of Economic Behaviour \& Organization, Vol. 76, Issue , pp. 563-573.

Pew Research Center - USA. (2017). Gender Discrimination Comes in Many Forms for Today's Working Women.

Ryan, M., Haslam, S., Morgenroth, T., Rink, F., Stoker, J., Peters, K. (2015). Getting on Top of the Glass Cliff: Reviewing a Decade of Evidence, Explanations and Impact. The Leadership Quarterly, Vol. 27, No. 3, pp. 446-455.

Rycx, F., Tojerow, I. (2004). Rent Sharing and the Gender Wage Gap in Belgium. International Journal of Manpower, Vol. 25, No. 3/4, pp. 279-299.

Sabiedrības integrācijas fonds. (2014). Sieviešu un vīriešu situācijas izpēte Latvijas lielajos uzñēmumos.

Sayers, R., Levendis, J., Dicle, M. (2017). The Sexual Orientation Wage Gap in the USA. International Journal of Social Economics, Vol. 44, No. 12, pp. 1846-1855.

Scicchitano, S. (2014). The Gender Wage Gap among Spanish Managers. International Journal of Manpower, Vol. 35 , No. 3, pp. 327-344.

Shannon, M., Kidd, M. P. (2005). Projections of the Future Path of the Gender Wage Gap in Great Britain. International Journal of Manpower, Vol. 26, No. 4, pp. 350-363.

Šilingiene, V., Radvila, G. (2014). Gender Differences of Wage Trends in the Baltic States. Procedia-Social and Behavioral Sciences, Vol. 156, pp. 98-101.

Šimanskienè, L., Sandu, L. (2013). Methods of Assessment of Organisational Culture. Regional Formation \& Development Studies, Vol. 10, pp. 201-210.

Vokic, N., Coric, D., Obadic, A. (2017). To be or not to be a Woman? Highly Educated Women's Perceptions of Gender Equality in the Workplace. Review of Social Policy, Vol. 24, No. 3, pp. 253-276. 


\title{
DARBOUŽMOKESČIO S KIRTUMAS, KAIP GALIMAS LYČIU NELYGYBËS VEIKSNYS
}

\author{
Sabine Anete Vasina, Biruta Sloka \\ Latvijos universitetas (Latvija)
}

Santrauka

Šiandien daugelyje šalių moterys aktyviai dalyvauja darbo rinkoje. Spartūs ekonominiai pokyčiai gali lemti socialinio vaidmens sistemos pokyčius, kurie vykdyti šimtmečiais, siekiant, kad moterys galètu igyti išsilavinimą ir dalyvauti darbo rinkoje, taip išlaikyti savo namų ūkius. Apskritai moterys tapo labiau nepriklausomos ir sąmoningiau suvokia savo vaidmenį visuomenèje, užimdamos įvairias pareigas tiek privačiame, tiek viešajame sektoriuose.

Kartu su moterų dalyvavimu darbo rinkoje daugelio visuomenių dėmesys atkreiptas ị galimus XXI amžiaus darbuotojų trūkumus, pavyzdžiui, skirtingus užimtumo lygius ir neišmatuojamus, bet pastebimus barjerus, kurie riboja daugelio moterų karjeros galimybes. Šios aplinkybẻs gali lemti vyrų ir moterų išsilavinimo bei karjeros pasirinkimą, kas savo ruožtu lemia lyčių dominavimą ir galbūt darbo užmokesčio skirtumus tam tikruose ekonomikos sektoriuose.

Galima teigti, kad darbo užmokesčio skirtumų atsiranda dėl menko moterų dalyvavimo darbo rinkoje, taip pat darbo visą ar ne visą darbo dieną pasirinkimo, atsižvelgiant ị asmenines priežastis, pavyzdžiui, vaikų priežiūrą. Naujausi moksliniai tyrimai atskleide, kad įvairiose šalyse, profesijose ir ekonomikos sektoriuose yra darbo ir darbo užmokesčio skirtumų.

Tyrimo objektas - lyčių nelygybė profesinès segregacijos ịvairiuose ekonomikos sektoriuose bei nelygybès darbo pajamų bruto ir neto Latvijoje 2015-2018 m. kontekste.

Tyrimu siekta išanalizuoti naujausius mokslinius duomenis apie darbo užmokesčio skirtumus, atsižvelgiant ị lytị, ir analizuoti empirinius duomenis Latvijoje taikant EU-SILC apklausas, darbo tyrimus ir mėnesio statistinius duomenis apie moterų ir vyrų darbo užmokestį.

Rezultatai atskleidè, kad ịvairiose ekonomikos srityse ir profesijose moterims nepakankamai atstovauta, daugelio sričiu moterų modalinis grynojo darbo užmokesčio intervalas buvo mažesnis nei vyrams taikomas modalinis darbo užmokesčio intervalas. Be to, nustatyti statistiškai reikšmingi skirtumai 2018 m. sausio mèn. moterų ir vyrų vidutinių bruto pajamų atžvilgiu, kas patvirtina, kad vyrai vidutiniškai uždirbo daugiau nei moterys.

PAGRINDINIAI ŽODŽIAI: darbo užmokesčio skirtumas, nelygybè, „,stiklinès lubos “. 